Journal of Contemporary Research in Business, Economics and Finance

ISSN: 2641-0265

Vol. 3, No. 2, pp. 39-47.

2021

Publisher: Learning Gate

DOI: 10.33094/26410265.2021.32.39.47

(C) 2021 by the authors; licensee Learning Gate

\title{
Public Debt and Economic Growth in Switzerland
}

\author{
Daniel Lim \\ University of Bern, Switzerland. \\ Email: Daniel.lim@,ibmm.unibe.ch \\ Michael Groschek \\ University of Bern, Switzerland.
}

Received: 5 March 2021; Revised: 7 June 2021; Accepted: 25 June 2021 ; Published: 9 August 2021

\begin{abstract}
Economic theory suggests that a realistic level of borrowing is beneficial for both developing and developed economies in achieving sustainable level of economic growth. However, as a result of insufficient domestic resources to fund the "development projects", required for the economic progress, most of the countries strongly rely on internal (domestic) and external (international) capitals such as public debt, foreign direct investment (FDI) and remittances. Keeping in mind this significance, this study analyzes the role of public debt, FDI and remittances in accelerating the economic growth in Switzerland. For getting this purpose achieved, the study gathers the data from world development indicators (WDI) for the period of 1997-2016. The study uses public debt, FDI and remittances as predictors, while economic growth is taken as outcome variable. The study applies auto regressive distributive lag (ARDL) model to analyze the data. Results of the study show positive influence of public debt, FDI and remittances on the economic growth of Switzerland which is in line with the economic theory. Based on the findings, the study suggests articulating and implementing policies aimed at attracting more inflows of foreign capital that will positively contribute to economic growth in the long run. The study furthers the government of Switzerland to keep debts to the GDP threshold as low as possible.
\end{abstract}

Keywords: Public Debts, Foreign Direct investment, Remittances, Economic growth.

\section{Introduction}

Economic growth is the issue of prime concern of governments of both developed and developing economies. Each country requires a substantial amount of capital to strain production and their sustained economic activity. In the situation, when the spending of government exceeds from its collection of tax, the country faces deficit in its budget that can be financed by borrowing the money either from the private sector, or from the foreign government (Mankiw, 2000). Economic theory suggests that a realistic level of borrowing is beneficial for both, developing and developed nations to achieve the sustainable level of economic growth. However, as a result of insufficient domestic resources to fund the "development projects", required for the economic progress, many nations strongly rely on the internal (domestic) and external (international) capitals i.e., public debt (PD), foreign direct investment (FDI), official development assistance (ODA), cross-border interbank borrowing (CBIB), concessional loans (CL) and remittances (RT) etc.

Normally, when the tax revenue falls short of the estimate of expenditures of government, then the governments have no other options to escalate the tax, or borrow nationally or internationally (OwusuNantwi \& Erickson, 2016). When governments choose to borrow money (which is an another way to elude tax burdens), it leads to the public debt (Ogunmuyiwa, 2011). Public debt, therefore, refers to the short-term and long-term loans, obtained by the governments to finance the public expenditures as an 
outcome of deficient public revenues. Public debt is an efficient source of funding over the years which is parallel to the size of government (Ouedraogo, 2015). After the second world war, many countries (including developing and developed) depends on the internal or external borrowing to deal with the global economic recession, and to fund their budget deficits. Due to this borrowing, most of the countries face temporary relief from the economic problems i.e., S-I gap, unemployment etc., but it imposes long term detrimental effects on the economic growth (EG) in early 2000 in some developing economies. However, this borrowing results in an improvement in the EG of highly developed and advanced economies (i.e., for the case of member nations of European nation) (Donayre \& Taivan, 2017). As a result, academic and policy debate on the causal relationship between PD and EG had been started. For instance, some researchers supported the positive relationship between PD and EG (Egbetunde, 2012; Owusu-Nantwi \& Erickson, 2016). While, other researchers indicated the negative relationship between PD and EG by indicating the harmful effects of PD for the economic development (Panizza \& Presbitero, 2014; Rais \& Anwar, 2012).

In addition to PD, FDI is another important factor of having substantial effects on the EG. FDI, as a supplementary foreign capital to domestic capital stock is perceived as an essential driver of the EG of developed, developing, emerging and transition countries, because the magnetism of FDI can promote the formulation of capital which resultantly increases the economic progress (Ayanwale, 2007). FDI also strengthens the inadequate domestic funds to finance both, ownership alteration and capital composition (Azman-Saini \& Law, 2010)

In addition to this, the inflows of FDI contributes to the economic progress of the nation via increased productivity, and better managerial and technological skill to the host nation which is very beneficial for the economic development (Mielnik \& Goldemberg, 2002). Alike FDI, RT is also an important factor which positively contributes to the EG. RTs represent a major part of worldwide capital flows, consummating FDI, export revenues and foreign aid (Giuliano \& Ruiz-Arranz, 2009). A recent report, published by the world bank, suggests that documented remittances have grown faster than FDI. Researchers explained different channels through which the RT promotes EG. First, RT tends to increase the personal disposable income of the people which in turn increases their consumption patterns which result in an increase in the aggregate demand of the nation with the multiplier effect (Cazachevici, Havranek, \& Horvath, 2020). Second, RT tends to increase the personal investments of the people. This eliminates the negative impact of inadequate savings on the economic progress of the nation and thus indirectly contributes to the economic development. Third, RT positively contribute to the development of the financial sector. Researchers argued that the development of the financial sector will reduce the S-I gap and the nation will face the rapid economic progress.

Summing up the discussion from above, the respective study perceives the significant and positive role of PD, FDI and RT on the EG of both developing and developed nations. But surprisingly, most of the researchers have investigated the role of PD, FDI and RT on the EG of the developing economies, and the role of FDI in the economic progress of the developed economies is very less focused by the prior researchers. Moreover, if we talk about PD-EG nexus, the findings are still very confusing as some researchers indicated the positive role of $\mathrm{PD}$ on EG while other indicated its negative role. Present study, therefore, contributes to the existing debate by analyzing the collective impact of PD, FDI and RT on EG, specifically for the case of Switzerland. Therefore, the aim of the study is to analyze the role of PD, FDI and RT in enhancing EG. The rest study has structured as: next section comprises of review of past studies, third section has discussed the econometric methods, the following section provides empirical results with hypotheses testing and last section concludes the research.

\section{Literature Review}

\subsection{Public Debt (PD) and Economic Growth (EG)}

According to the economic theory, rational amount of borrowing by the emerging nations are likely to promote their economic progress (Greiner \& Fincke, 2009). This indication motivates the researchers to publish their studies in different academic journals, and hence, public debt and economic growth 
remains highly debated area among the researchers. Some of the researcher revealed the positive relationship between $\mathrm{PD}$ and EG, while other reveals the negative relationship. For instance, Egbetunde (2012) tested the casual linkage between PD and EG for the case of Nigeria from 1970 to 2010 and indicated two-way casualty between PD and EG. The study concluded that PD can be beneficial for the economic progress of the nation if the government is honest. i.e., if government use this debt for the expansion of economy, instead of using it for their own benefit. Owusu-Nantwi and Erickson (2016) also found the positive relationship between PD and EG in Ghana for the period of 1970-2012. The study concluded that in the developing economies PD not only advances the economic progress of the nation, but also improves the living standards and well-being of the people. Casares (2015) investigated the role of external public debt on the EG of Malaysia and indicated the positive relationship between PD and EG in short run while the negative relationship between PD and EG in long run. Similarly, Shahor (2018) also indicated the positive relationship between PD and EG. However, in contradict to these researchers, many researchers highlighted the negative role of PD on EG and indicated that PD exerts the burdens on the current account of the developing nations which resultantly reduces the EG. Panizza and Presbitero (2014) empirically tested the linkage between PD and EG by using a novel instrumental approach. The study added some instrumental variables in the model to get precise and accurate results. Results of the study showed that continuous increase in the level of PD is detrimental for the economic progress. Similarly Rais and Anwar (2012) also found the negative relationship between PD and EG for the case of Pakistan. The study concluded that if a country has high level of debts, the government has no inducement to announce macro-economic policies or reforms because the returns of these macroeconomic policies will only be used to refund unpaid debt. Akram (2011) also found the negative relationship between PD and EG. After reviewing the above literature, present study proposes that there is a huge need to reinvestigate the relationship between PD and EG because the previous findings on the PD-EG nexus do reach at a definite conclusion. Moreover, to the best of our knowledge, most of the researchers have investigated the role of public debt for the case of developing or emerging nations, and the role of public debt on the economic progress of the developed nations are under researched. Present study, therefore, contributes to the existing debate of PD-EG by analyzing the role of PD on EG for the case of Switzerland, a developed economy. Hence, it is hypothesized that:

$H_{l}$ : There is a significant relationship between PD and EG.

\subsection{Foreign Direct Investment (FDI) and Economic Growth (EG)}

FDI-EG nexus is also a highly debated area in the field of economics. Researchers believed that FDI is an important source of external financing which can positively contribute to the economic development. Researchers believed that the assistance of aid reduces the resource gap between the developed and developing economies (Ayanwale, 2007). Azman-Saini and Law (2010) indicated that many developing economies are facing different financial constraints which are the barriers in the economic progress. The study believed that FDI reduces these barriers and promotes the EG in a country. The study, hence, concluded the positive relationship between FDI and EG. Siddique, Ansar, Naeem, and Yaqoob (2017) also indicated the positive role of FDI in accelerating the economic growth of the developing economies for the period of 1970-2010. Sakyi and Egyir (2017) conducted their research in Bangladesh to highlight the role of FDI on the economic progress. For this purpose, the study gathered the data for the period of 1995-2018 from world bank and found the positive role of FDI on EG. The study perceives FDI as a financial assistance from the external resources. Asamoah, Mensah, and Bondzie (2019) gathered the data of 86 developing and emerging economies for the period of 1980-2007 to analyze the role of FDI on EG and found the positive affiliation between FDI and EG. Similarly, Wu, Yuan, Wang, Cao, and Zhou (2020) also indicated the positive role of FDI on EG. The study concluded that FDI not only helps to promote the economic growth, but is also a significant determinant of inequality and poverty reduction. Tien and Thuy (2020) also revealed the positive relationship between FDI and EG. Author believed that FDI is an effective mode of foreign inflows in 
the nation which positively contributes to EG. Sargsyan (2017) worked in the context of two-gap model and indicated that role of FDI in EG is based on the effectiveness of the country governance. Jena and Sethi (2019) reveled the positive effects of FDI in the achievements of development goals and hence concluded the positive relationship between FDI and EG. Modou and Liu (2017) also indicated the positive role of FDI in accelerating the economic growth of the developing economies for the period of 1980-2018. Considering the above literature, present study considers that most of the researchers have investigated the role of FDI in the EG of the developing economies, and the role of FDI on the economic progress of the developed economies is very less focused by the prior researchers. Present study, therefore, contributes to the existing debate by analyzing the role of FDI in EG for the case of Switzerland, a developed economy. Hence, it is hypothesized that:

$H_{2:}$ There is a positive relationship between FDI and EG.

\subsection{Remittances (RT) and Economic Growth (EG)}

Remittances-growth nexus has received a huge consideration from different researchers and the policy makers. Researchers indicated that remittance is one of the important driving factor for the economic development. For instance, Cazachevici et al. (2020) believed that the inflow of RT provides the source of additional income to the people in the underdeveloped or the emerging economies which boost up the demand with the effect of multiplier. As a result, industries respond by increasing production and thus economy grows. The authors concluded the positive relationship between RT and EG. Giuliano and Ruiz-Arranz (2009) utilized the data of seven Mediterranean countries to investigate the empirical link between RT and EG. By applying a novel Keynesian type econometric model, the study found the positive relationship between RT and ED. Sutradhar (2020) also indicated the positive role of RT and EG. Authors believed that RT is the second source of foreign funding. Abduvaliev and Bustillo (2020) examined the bond between worker's RT and EG for the case of different South Asian economies. In this regard, the study gathered the data for the period of 1977-2016. The study applied pooled regression to estimate the findings. Results of the study showed the positive role of RT on EG. Cazachevici et al. (2020) indicated that RT is a vital source of the external financing for the developing economies which imposes positive effects on its economic development in the form of urging investment and relieving credit constraints. Eggoh, Bangake, and Semedo (2019) worked on the sample of 49 developing and emerging economies to investigate the role of RT on EG. For this purpose, the study collected the data for the period of 2001-2013 using smooth transaction panel model to estimate the results. Results of the study indicated the positive bonds between RT and EG. Considering the above literature, present study considers that most of the researchers have investigated the role of RT in the EG of the developing economies, and the role of RT in the economic progress of the developed economies is very less focused by the prior researchers. Present study, therefore, contributes to the existing debate by analyzing the role of RT on EG for the case of Switzerland and supposed that:

$H_{s}$ : There is a positive relationship between $R T$ and $E G$.

\section{Econometric Methodology}

\subsection{Data Sources and Variables}

Present study intends to examine the role of PD, FDI, and RT on EG. For this purpose, the study gathers the data from Switzerland for the period of 1997-2016 from world development indicators (WDI). The study has used PD, FDI and RT as predictors, while EG as outcome variable. PD is measured as central government debt (as \%age of GDP), FDI is measured as net inflows (as \%age of GDP) and remittances are measured as \%age of GDP; and EG is measured as annual \%. Present study has used following econometric model to estimate the empirical results:

$$
E G=\beta_{0}+\beta_{1} P D_{\mathrm{t}}+\beta_{2} F D I_{\mathrm{t}}+\beta_{3} R T_{\mathrm{t}}+u_{\mathrm{t}}
$$


Where: EG is economic growth, PD is public debt, FDI is foreign direct investment, RT is remittances, $\beta_{0}$ is intercept, $\beta_{1}-\beta_{a}$ are slope coefficients, and $u_{t}$ is stochastic error term which is assumed to be normally distributed.

\subsection{Estimation Techniques}

Present study applies auto regressive distributive lag (ARDL) model to analyze the impact. The modeling approach of ARDL was first pioneered by Pesaran, Shin, and Smith (1999) later in Pesaran, Shin, and Smith (2001) further extended this technique. This technique is considered as the most appropriate to use while working with small sample sizes (Ahmed, Kousar, Pervaiz, \& Ramos-Requena, 2020). Many researchers have applied this co-integration technique to test long-run association among the variables for the case of small samples. However, before proceeding to the ARDL test, the study applies some diagnostic tests (test of autocorrelation, heteroscedasticity and multicollinearity) to make sure that the data are free from the econometric and statistical errors. Test of stationarity is also a prerequisite for the present study, as the data for the respective study is of time series in nature. Present

study, therefore applies well-known and extensively applied ADF unit-root test to determine the stationary properties and order of integration of the data. Keeping in mind the stationary properties and order of integration of the data, the study applies ARDL bound testing approach to test the long run relationship among modeled variables. ARDL bound testing approach used Equation 2 to test the cointegrating relation among the chosen variables for the selected time period.

$$
\begin{aligned}
& \Delta E G_{t}=a_{0}+\sum_{i=1}^{q} \vartheta_{0} \Delta E G_{t-i}+\sum_{i=0}^{q} \delta_{1} \Delta(P D)_{t-i}+\sum_{i=0}^{q} \delta_{2} \Delta(F D I)_{t-i}+\sum_{i=0}^{q} \delta_{a} \Delta(R T)_{t-i}+\gamma_{0}(E G)_{t-i}+ \\
& \beta_{1}(P D)_{t-i}+\beta_{2}(F D I)_{t-i}+\beta_{a}(R T)_{t-i}+\mu_{t}
\end{aligned}
$$

Where: EG is economic growth, PD is public debt, FDI is foreign direct investment, RT is remittances, $\Delta$ is the difference operator, $\alpha_{0}$ is the intercept, $\vartheta_{0}, \delta_{1}-\delta_{a}$ are the coefficients of short run, while $\gamma_{0}, \beta_{1}-\beta_{a}$ are the coefficients of long run. The equation uses $\mathrm{F}$-statistics to test the cointegrating relation among the chosen variables. This test involves the testing of the null hypothesis of "nocointegration" by assuming "a zero joint restriction" on the $\beta_{g}$ in the error correction (ECM) model (i.e., $\mathrm{H}_{0}: \beta_{1}=\beta_{2}=\beta_{a}=0$ ). The asymptotic distributions of the test statistics are "non-standard" unrelatedly of whether the variables are integrated of order 0 i.e., I (0), or integrated of order 1 i.e., I (1). Therefore, the test computes the two sets of asymptotic critical values where the first set hypothesized that variables are I (0) [known as lower bound], while the other set assumes that variables are I (1) [known as upper bound]. These upper and lower bounds help in making the decision regarding the presence of long run relationship between the variables. If the computed $\mathrm{F}$-statistics are greater than upper bound, then it is concluded that long run relation exists among modeled variables.

After examining the long run relationship between variables, the study used Equation 3 to estimate short run parameters and the error correction term (ECT).

$$
\Delta E G_{\mathrm{t}}=\alpha_{0}+\sum_{\mathrm{i}=1}^{q} \vartheta_{0} \Delta E G_{\mathrm{t}-\mathrm{i}}+\sum_{\mathrm{i}=0}^{\mathrm{q}} \delta_{1} \Delta(P D)_{\mathrm{t}-\mathrm{i}}+\sum_{\mathrm{i}=0}^{\mathrm{q}} \delta_{2} \Delta(F D I)_{\mathrm{t}-\mathrm{i}}+\sum_{\mathrm{i}=0}^{\mathrm{q}} \delta_{\mathrm{a}} \Delta(R T)_{\mathrm{t}-\mathrm{i}}+\psi(E C M)_{\mathrm{t}-1}+\mu_{\mathrm{t}}
$$

Where; $\Delta$ is the first difference operator, $\alpha_{0}$ is the intercept term, $\theta_{0}, \delta_{1}-\delta_{a}$ are the slope coefficients of short run, $\mathrm{ECM}_{\mathrm{t}-1}$ is the error correction term, which signifies the speed of adjustment or the level of long run equilibrium, and $\mu_{\mathrm{t}}$ is the residual or stochastic error term.

\section{Estimation Results}

\subsection{Descriptive Statistics}

Present study begins its analysis with the descriptive statistics. Results are reported in Table 1. Table also reports the test statistics and the probability value of Jarque-Bera to test the normality of residuals. The insignificant p-values indicate the normality of residuals. 
Table-1.

Descriptive Statistics.

\begin{tabular}{c|c|c|c|c}
\hline Particulars & EG & FDI & PD & RT \\
\hline Mean & 2.0673 & 5.8239 & 23.9757 & 0.3862 \\
\hline Median & 2.1571 & 3.5666 & 23.9235 & 0.3994 \\
\hline Maximum & 4.0150 & 24.012 & 29.5320 & 0.4223 \\
\hline Minimum & -2.0796 & -3.4972 & 19.0457 & 0.3276 \\
\hline Std. Dev. & 1.5003 & 6.2300 & 3.44247 & 0.0299 \\
\hline Skewness & -1.0382 & 1.4302 & 0.2769 & -0.4545 \\
\hline Kurtosis & 4.1595 & 5.0113 & 1.7664 & 1.7546 \\
\hline Jarque-Bera & 4.7134 & 1.1903 & 1.5237 & 1.9810 \\
\hline Probability & 0.0947 & 0.3361 & 0.4667 & 0.3713 \\
\hline Observations & 20 & 20 & 20 & 20 \\
\hline
\end{tabular}

Note: EG is economic growth, FDI is foreign direct investment, PD is public debt, and RT is remittances.

\subsection{Test of Stationary}

The study applies ADF unit root to test the stationarity of variables. The test is applied on level and first difference in two cases (i.e., intercept only, and trend and intercept). Results are reported in Table 2. Results indicate that EG and FDI are free from the problem of unit-root as the test statics are significant at level in both cases (i.e., intercept, and intercept and trend). However, the series of PD and RT are non-stationary at level in both cases. These series become stationary at first difference by rejecting the null hypothesis of non-stationary series at $1 \%$ level of significance.

Table-2.

Test of Unit Root

\begin{tabular}{|c|c|c|c|c|c|}
\hline \multirow{3}{*}{ Variables } & \multicolumn{4}{|c|}{ Augmented Dickey Fuller test } & \multirow[b]{3}{*}{ Decision } \\
\hline & \multicolumn{2}{|r|}{ Level } & \multicolumn{2}{|c|}{ First difference } & \\
\hline & Intercept & Intercept and trend & Intercept & Intercept and trend & \\
\hline EG & $-3.8979^{* * *}$ & $-4.7345^{* * * *}$ & $-5.8947 * * *$ & $-6.0833^{* * * *}$ & $\mathrm{I}(\mathrm{O}), \mathrm{I}(1)$ \\
\hline $\mathrm{PD}$ & -0.6601 & -1.5616 & $-5.7756^{* * * *}$ & $-4.6043^{*} *$ & $\mathrm{I}(1)$ \\
\hline FDI & $-2.4431^{*}$ & $-2.84132^{*}$ & $-3.8903^{* * *}$ & $-3.8979^{* *}$ & $\mathrm{I}(\mathrm{O}), \mathrm{I}(1)$ \\
\hline RT & -2.1437 & -2.8378 & $-5.3155^{*} * * *$ & $-3.4862^{*}$ & $\mathrm{I}(1)$ \\
\hline
\end{tabular}

Note: EG is economic growth, FDI is foreign direct investment, PD is public debt, RT is remittances, ${ }^{*}, * * * * * *$ is significance at the level of $10 \%, 5 \%$, and $1 \%$ respectively.

Table-3.

Diagnostic Tests.

\begin{tabular}{c|c|c|c|c}
\hline \multicolumn{2}{l}{ Panel A: Correlation Matrix } & PD & EG & RT \\
\hline Variables & FDI & & & \\
\hline FDI & 1 & 1 & & \\
\hline PD & -0.3279 & 0.04295 & 1 & \\
\hline EG & 0.01058 & 0.12575 & -0.2145 & 1 \\
\hline RT & -0.16858 & & &
\end{tabular}

\begin{tabular}{l|c|c|c}
\hline Panel B: Test of serial correlation & \multicolumn{4}{|l}{} \\
\hline Breusch-Godfrey Serial Correlation & Test statistic & P-value & Decision \\
\cline { 2 - 4 } & 1.7634 & 0.2445 & \\
\hline Panel C: Test of heteroscedasticity & \multicolumn{1}{|l}{} \\
\hline Breusch-Pagan-Godfry HSK & Test statistic & P-value & Decision \\
\cline { 2 - 4 } & 0.9023 & 0.3845 & \\
\hline
\end{tabular}




\subsection{Diagnostic Tests}

The study applies some diagnostic test to detect the presence of econometric errors in the data. The results are reported in Table 3. Results of Panel A of Table 3 show that the problem of multicollinearity doesn't exist in the data as the coefficient of correlation between 2 variables is less than 0.5. Meanwhile, the insignificant probability values, reported in panel B and C indicated that the data for the present study are free from the problem of, serial correlation, and heteroscedasticity respectively.

\subsection{Bounds Test}

Table 4 reports the results of bounds test which is used to test the long run relationship between variables. Bound test is having the null hypothesis of "no-cointegration". The rejection of this hypothesis shows the cointegrating relation among the modeled variables. The results of the bounds cointegration tests are reported in Table 4. Table shows that the value of $\mathrm{F}$ statistic (9.0211) is greater than upper bound at the significance level of $10 \%, 5 \%$ and $1 \%$. So here it is concluded that cointegration exist among the chosen variables and the variables move together in the long run.

Table-4.

Bounds Test.

\begin{tabular}{c|c|c|c|c}
\hline \multicolumn{2}{c|}{ F-Bounds Test } & \multicolumn{3}{c}{ Null Hypothesis: No cointegration relationship } \\
\hline Test Statistic & Value & Significance & $\mathbf{I}(\mathbf{0})$ & $\mathbf{I}(\mathbf{1})$ \\
\hline \multirow{2}{*}{ F-statistic } & \multirow{2}{*}{9.021136} & $10 \%$ & 2.97 & 3.74 \\
\cline { 3 - 5 } & & $5 \%$ & 3.38 & 4.23 \\
\hline \multirow{2}{*}{$K$} & \multirow{2}{*}{3} & $2.5 \%$ & 3.8 & 4.68 \\
\cline { 3 - 5 } & & $1 \%$ & 4.3 & 5.23 \\
\hline
\end{tabular}

\subsection{Hypotheses Testing}

Present study applies ARDL to test the hypothesized relationship between variables in long run. Results are reported in Table 5. Panel A of Table 5 shows the ECM value, which shows the speed of adjustment between independent and dependent variables. Result of ECM shows that about $78.63 \%$ of inconsistency between long term and short-term EG can be corrected within a year at $1 \%$ level of significance.

Panel $\mathrm{B}$ of Table 5 reports the long run relationship between variables. It shows that PD, FDI and $\mathrm{RT}$ is having the significant and positive influence on EG at the level of $1 \%, 1 \%$, and $5 \%$ respectively. Hence, all the hypotheses of the study are supported. Results indicate that 1-unit of increase in PD results an increase of 0.1683 units in EG. Similarly, 1-unit od increase in FDI leads to 0.4394 units increase in EG, and 1-unit of increase in RT tends to increase 0.5910 units of EG.

Table-5.

Hypotheses Testing.

\begin{tabular}{|c|c|c|c|}
\hline \multirow[t]{2}{*}{ Independent Variables } & \multicolumn{2}{|c|}{ Dependent variable: EG } & \multirow[t]{2}{*}{ Decision } \\
\hline & Coefficient & P-value & \\
\hline \multicolumn{4}{|l|}{ Panel A: ECM regression } \\
\hline $\operatorname{ECM}(-1)$ & $-0.7863^{* * * * *}$ & 0.0000 & -- \\
\hline \multicolumn{4}{|l|}{ Panel B: Long run results } \\
\hline $\mathrm{PD}$ & $0.1683^{*} * * *$ & 0.0407 & H1: Supported \\
\hline FDI & $0.4394 * * *$ & 0.0231 & H2: Supported \\
\hline $\mathrm{RT}$ & $0.5910^{* *}$ & 0.0357 & H3: Supported \\
\hline Adjusted R-square & \multicolumn{3}{|c|}{0.6846} \\
\hline
\end{tabular}




\section{Discussion, Conclusion and Policy Recommendations}

Economic growth is the significant issue for the governments of both developed and developing economies. Each country requires a substantial amount of capital to strain production and their sustained economic activity. In the situation, when the spending of government exceeds from its collection of tax, the country faces deficit in its budget that can be financed by borrowing the money either from the private sector, or from the foreign government. Economic theory suggests that a realistic level of borrowing is beneficial for both developing and developed nations to achieve the sustainable level of economic growth. However, as a result of insufficient domestic resources to fund the "development projects", required for the economic progress, many nations strongly rely on the internal (domestic) and external (international) capitals i.e., PD, FDI and RT. Hence, present study analyzes the role or PD, FDI and RT in the EG. For this purpose, the study gathers the data from Switzerland for the period of 1997-2016 from world development indicators (WDI). The study uses PD, FDI and RT as independent variables, while EG as dependent variable and applies auto regressive distributive lag (ARDL) model to analyze the results.

Results of the study show a positive influence of PD, FDI and RT on the EG of Switzerland. Results of the study are aligned with prior researchers (Azman-Saini \& Law, 2010; Cazachevici et al., 2020; Egbetunde, 2012; Owusu-Nantwi \& Erickson, 2016; Sakyi \& Egyir, 2017; Sutradhar, 2020). The study suggests that there is a need to implement and articulate policies aimed at attracting more inflows of foreign capital (i.e., RT and FDI), which will positively contribute to economic growth in the long run. The study further suggests that the government should keep the debt to GDP threshold as low as possible.

\section{References}

Abduvaliev, M., \& Bustillo, R. (2020). Impact of remittances on economic growth and poverty reduction amongst CIS countries. Post-Communist Economies, 32(4), 525-546. Available at: https://doi.org/10.1080/14631377.2019.1678094.

Ahmed, F., Kousar, S., Pervaiz, A., \& Ramos-Requena, J. P. (2020). Financial development, institutional quality, and environmental degradation nexus: New evidence from asymmetric ARDL co-integration approach. Sustainability, 12(18), 7812. Available at: https://doi.org/10.3390/su12187812.

Akram, N. (2011). Impact of public debt on the economic growth of Pakistan. The Pakistan Development Revierw, 50(4), 599-615. Available at: https://doi.org/10.30541/v50i4iipp.599-615.

Asamoah, L. A., Mensah, E. K., \& Bondzie, E. A. (2019). Trade openness, FDI and economic growth in sub-Saharan Africa: Do institutions matter? Transnational Corporations Review, 11(1), 65-79. Available at: https://doi.org/10.1080/19186444.2019.1578156.

Ayanwale, A. B. (2007). FDI and economic growth: Evidence from Nigeria.

Azman-Saini, W. N. W., \& Law, S. H. (2010). FDI and economic growth: New evidence on the role of financial markets. Economics Letters, 107(2), 211-213. Available at: https://doi.org/10.1016/j.econlet.2010.01.027.

Casares, E. R. (2015). A relationship between external public debt and economic grow th. Estudios Económicos, 30(2), $219-243$.

Cazachevici, A., Havranek, T., \& Horvath, R. (2020). Remittances and economic growth: A meta-analysis. World Development, $134,105021$.

Donayre, L., \& Taivan, A. (2017). Causality between public debt and real growth in the OECD: A country-by-country analysis. Economic Papers: A Journal of Applied Economics and Policy, 36(2), 156-170.

Egbetunde, T. (2012). Public debt and economic growth in Nigeria: Evidence from granger causality. American Journal of Economics, 2(6), 101-106. Available at: https://doi.org/10.5923/j.economics.20120206.02

Eggoh, J., Bangake, C., \& Semedo, G. (2019). Do remittances spur economic growth? Evidence from developing countries. The Journal of International Trade \& Economic Development, 28(4), 391-418. Available at: https://doi.org/10.1080/09638199.2019.1568522.

Giuliano, P., \& Ruiz-Arranz, M. (2009). Remittances, financial development, and growth. Journal of Development Economics, 9O(1), 144-152.

Greiner, A., \& Fincke, B. (2009). Public debt and economic growth Springer Science \& Business Media, 11.

Jena, N. R., \& Sethi, N. (2019). Foreign aid and economic growth in sub-Saharan Africa. African Journal of Economic and Management Studies, $11(1), 147-168$.

Mankiw, N. G. (2000). The savers-spenders theory of fiscal policy. American economic review, 90(2), 120-125. Available at: https://doi.org/10.3386/w7571.

Mielnik, O., \& Goldemberg, J. (2002). Foreign direct investment and decoupling between energy and gross domestic product in developing countries. Energy Policy, 30(2), 87-89. Available at: https://doi.org/10.1016/s0301-42 15(01)00080-5

Journal of Contemporary Research in Business, Economics and Finance
ISSN: $2641-0265$
Vol. 3, No. 2, pp. $39-47,2021$
DOI: $10.33094 / 26410265.2021 .32 .39 .47$
(C) 2021 by the authors; licensee Learning Gate


Modou, D., \& Liu, H. Y. (2017). The impact of Asian foreign direct investment, trade on Africas economic growth. International Journal of Innovation and Economic Development, 3(1), 72-85. Available at: https://doi.org/10.18775/ijied.1849-75517020.2015 .31 .2004 .

Ogunmuyiwa, M. S. (2011). Does external debt promote economic growth in Nigeria. Current research journal of economic theory, $3(1), 29-35$.

Ouedraogo, J. (2015). External debt, quality of institutions, and economic growth in WAEMU. In Regional Integration and policy challenges in Africa. London: Palgrave Macmillan.

Owusu-Nantwi, V., \& Erickson, C. (2016). Public debt and economic growth in Ghana. African Development Review, 28(1), 116126. Available at: https://doi.org/10.1111/1467-8268.12174.

Panizza, U., \& Presbitero, A. F. (2014). Public debt and economic growth: Is there a causal effect? Journal of Macroeconomics, 41, $21-41$.

Pesaran, M. H., Shin, Y., \& Smith, R. J. (2001). Bounds testing approaches to the analysis of level relationships. Journal of Applied Econometrics, 16(3), 289-326. Available at: https://doi.org/10.1002/jae.616.

Pesaran, M. H., Shin, Y., \& Smith, R. P. (1999). Pooled mean group estimation of dynamic heterogeneous panels. Journal of the American Statistical Association, 94(446), 62 1-634. Available at: https://doi.org/10.1080/01621459.1999.10474156.

Rais, S. I., \& Anwar, T. (2012). Public debt and economic growth in Pakistan: A time series analysis from 1972 to 2010. Academic Research International, 2(1), 535-546.

Sakyi, D., \& Egyir, J. (2017). Effects of trade and FDI on economic growth in Africa: An empirical investigation. Transnational Corporations Review, 9(2), 66-87. Available at: https://doi.org/10.1080/19186444.2017.1326717.

Sargsyan, L. (2017). Impact of FDI on economic growth in the world and in Armenia. International Scientific Journal Internauka. Series: Economic Sciences, 5, 89-91.

Shahor, T. (2018). The impact of public debt on economic growth in the Israeli economy. Israel Affairs, 24(2), 254-264. Available at: https://doi.org/10.1080/13537121.2018.1429547.

Siddique, H. M. A. A., Ansar, R., Naeem, M. M., \& Yaqoob, S. (2017). Impact of FDI on economic growth: Evidence from Pakistan. Bulletin of Business and Economics, 6(3), 111-116.

Sutradhar, S. R. (2020). The impact of remittances on economic growth in Bangladesh, India, Pakistan and Sri Lanka. International Journal of Economic Policy Studies, 14(1), 275-295. Available at: https://doi.org/10.1007/s42495-02000034-1.

Tien, N. N., \& Thuy, N. T. T. (2020). Impact of FDI on economic growth from the sustainable development perspective: A case study from the assessment in the middle of Vietnam. Kasetsart Journal of Social Sciences, 41(3), 647-652.

Wu, W., Yuan, L., Wang, X., Cao, X., \& Zhou, S. (2020). Does FDI drive economic growth? Evidence from city data in China. Emerging Markets Finance and Trade, 56(11), 2594-2607. 